\title{
Author Correction: Effect of polymer type on the performance of a nanofiber mat actuator
}

\author{
Hanako Asai ${ }^{1} \cdot$ Tomotaka Okumura $^{1} \cdot$ Hiroaki Sakamoto $^{1} \cdot$ Koji Nakane $^{1}$
}

Published online: 25 March 2019

(C) The Society of Polymer Science, Japan 2019

\section{Correction to: Polymer Journal;}

https://doi.org/10.1038/s41428-018-0160-5; published online 17 December 2018

In the original published version of Table 1 and Table $\mathrm{S} 1$, the conductivity values are incorrect. The corrected Tables are as shown below.

Table 1 Characteristics of the three nanofiber mat electrodes

\begin{tabular}{llll}
\hline $\begin{array}{l}\text { Polymer } \\
\text { type }\end{array}$ & $\begin{array}{l}\text { Diameter of the fiber } \\
{[\mu \mathrm{m}]}\end{array}$ & $\begin{array}{l}\text { Conductivity } \\
{[\mathrm{S} / \mathrm{m}]}\end{array}$ & $\begin{array}{l}\text { Specific surface } \\
\text { area }\left[\mathrm{m}^{2} \mathrm{~g}^{-1}\right]\end{array}$ \\
\hline PU & $0.425 \pm 0.087$ & $3.0 \times 10^{2}$ & 4.94 \\
PMMA & $1.35 \pm 0.18$ & $2.0 \times 10^{2}$ & 3.23 \\
PVDF-HFP & $0.501 \pm 0.130$ & 50 & 4.09 \\
\hline
\end{tabular}

Table S1 The effect of additives on the conductivity of PMMA nanofiber mat

\begin{tabular}{lll}
\hline DMSO & Surfactant & Conductivity $[\mathrm{S} / \mathrm{m}]$ \\
\hline- & - & 0.13 \\
- & 0 & 30 \\
0 & - & 29 \\
0 & 0 & $2.0 \times 10^{2}$ \\
\hline
\end{tabular}

1 Frontier Fiber Technology and Science, Graduate School of Engineering, University of Fukui, 3-9-1 Bunkyo, Fukui 910-8507, Japan 